\title{
Response of ants to grazing disturbance at the central Monte Desert of Argentina: community descriptors and functional group scheme
}

\author{
Silvia CLAVER*, Susana L SILNIK, Florencia F CAMPÓN \\ Entomology Lab, IADIZA-CONICET, CCT Mendoza 5500, Argentina
}

\begin{abstract}
Livestock ranching is one of the main productive activities in arid regions of the world. Grazing produces changes in animal as well as plant communities (e.g. richness, abundance and species dominance relationships). Ants are good biological indicators due to the environmental fidelity of some of their community parameters. We described the functional structure of the ant community in the central Monte of Mendoza, Argentina, and examined the effect of grazing using richness, diversity and the functional group scheme. We used pitfall traps to sample ants at a reserve with 30-year cattle exclusion and at an adjacent ranch. Eleven of the 27 recorded species showed significant differences in their abundance and two species were absent at the ranch. While richness and diversity did not reflect these differences, functional groups did. Hot Climate Specialists were more abundant at the ranch while Cryptic Species and Generalized Myrmicinae increased at the reserve. This study supports the utility of the functional group scheme to study the effects of grazing disturbance in ant communities of arid regions.
\end{abstract}

Keywords: ants; cattle grazing; functional groups; richness; diversity; arid zones; Monte Desert

Citation: Silvia CLAVER, Susana L SILNIK, Florencia F CAMPÓN. 2014. Response of ants to grazing disturbance at the central Monte Desert of Argentina: community descriptors and functional group scheme. Journal of Arid Land, 6(1): 117-127. doi: 10.1007/s40333-013-0190-y

Neotropical arid areas, such as the Monte Desert in Argentina, are extensively exploited for natural resources extraction, agriculture and livestock ranching (Schofield and Bucher, 1986). At the central Monte, the most common exploitative activity outside the agricultural oasis is livestock ranching (Abraham et al., 2001). To monitor livestock disturbance in these habitats, it is possible to use species sensitive to disturbance as indicators.

Ants have proved to be useful indicators of ecological changes (Andersen and Majer, 2004). They are a dominant faunal group in most terrestrial ecosystems and mediate many key ecological processes (Folgarait, 1998). They have been shown to be sensitive to a wide variety of disturbance factors such as fire (Andersen et al., 2006), mining (Majer et al., 1984), habitat frag- mentation (Leal et al., 2012) and cattle raising (Schmidt et al., 2012) (though they seem to be resilient to invasive species disturbance; Osunkoya et al., 2011).

Although disturbance induces species composition changes, it does not necessarily affect overall species richness or abundance (Crist, 2009). Thus, traditional descriptors such as richness and diversity indices would not always be sensitive to changes in species abundance caused by disturbance. Functional groups, however, appear to be sensitive to these changes.

There are several studies on the response of functional groups of ants but most were carried out in tropical and subtropical areas (Osunkuyo et al., 2011; Leal et al., 2012) as they are sensitive to substantial change in habitat structure in these complex habitats (Hoffmann and Andersen, 2003), while they are ex-

*Corresponding author: Silvia CLAVER (E-mail: sclaver@mendoza-conicet.gov.ar)

Received 2012-11-15; revised 2012-12-24; accepted 2013-03-10

(C) Xinjiang Institute of Ecology and Geography, Chinese Academy of Sciences, Science Press and Springer-Verlag Berlin Heidelberg 2013 
pected to show less sensitivity (and be of less utility as disturbance indicators) in less structured habitats such as arid habitats.

Most studies on the response of ants to cattle raising have been carried out in Australia and the USA (for a review see Hoffmann, 2010), and only a few took place in South America (Bestelmeyer and Wiens, 1996; Claver, 2000; Tadey and Farji-Brener, 2007). In addition, besides the study by Bestelmeyer and Wiens (1996), the other studies focused on the response of only one species of ant to disturbance. Thus, there is a need for studies describing the functional structure of ant communities and its response to disturbance in arid areas.

In this study, we examined the effect of cattle presence on the ant community of the central Monte using descriptors such as richness and diversity as well as the functional group scheme. For the latter, we first described the functional structure of the ant community under natural conditions (reserve). In addition, we compared the functional structure of the ant community of the central Monte to those of other arid regions in the world.

\section{Materials and methods}

\subsection{Study area}

We studied the ant community of the mesquite forest at the Ñacuñán Biosphere Reserve, Santa Rosa, Mendoza, Argentina $\left(34^{\circ} 03^{\prime} \mathrm{S}, 67^{\circ} 58^{\prime} \mathrm{W}\right)$ and at an adjacent ranch with similar environmental characteristics except for the presence of livestock which had been excluded from the reserve since 1972 (Abraham et al., 2001). In the study area, the vegetation is an open mesquite forest of Prosopis flexuosa, with a shrub stratum dominated by Larrea divaricata, an herb stratum comprised mainly of perennial species and several annual herbs (Roig and Rossi, 2001). Vegetation at the ranch is similar to that of the reserve except for the marked absence of the herb stratum and an increase in bare soil (Kufner and Chabouleyron, 1991; Guevara et al., 1996; Gonnet, 1998). The weather is arid temperate with cold winters and marked seasonality and a mean annual precipitation of $337.5 \mathrm{~mm}$ concentrated during the summer. Annual mean tempera- ture is $15.6^{\circ} \mathrm{C}\left(\max : 42.5^{\circ} \mathrm{C}\right.$; $\left.\min :-13.0^{\circ} \mathrm{C}\right)$ (Estrella et al., 2001).

\subsection{Sampling design}

Ants were sampled using pitfall traps at four sites at the reserve and four other sites at an adjacent ranch. The vegetation structure of the ranch was less complex than that of the reserve area, with a lower percentage of grasses and herbal stratum, and a higher proportion of bare ground (Guevara et al., 1996). Reserve and ranch areas were $2-3 \mathrm{~km}$ apart, while sites within treatments were located at least $1 \mathrm{~km}$ apart, similar to Schnell et al. (2003) who assumed independence among sites. At each site, 12 pitfall traps were located $10 \mathrm{~m}$ apart and arranged in $20 \mathrm{~m} \times 30 \mathrm{~m}$ grids similar to Hoffman et al. (2000). Traps were functional during 30 days and relocated in different sites at each sampling period. Traps were plastic cups of $10 \mathrm{~cm}$ in diameter and $11 \mathrm{~cm}$ in height, filled with $200 \mathrm{~mL}$ of ethylene glycol. Ants were identified by species and assigned to functional groups.

\subsection{Functional groups}

We assigned each species or genera of ants to functional groups a priori based on the general concepts proposed by Greenslade and Andersen (Andersen, 1987, 1995). We also used published data from Bruch (1916), Bucher (1974), Claver and Fowler (1993), Bestelmeyer and Wiens (1996), Andersen (2000), Claver (2000) and personal observations (Claver) on the behaviour and natural history of ant species found in the Monte. We defined nine functional groups: Dominant Dolichoderinae (DD), Subordinate Camponotini (SCa), Hot Climate Specialists (HCS), Fungus-growing ants or Attini (At), Legionary ants or Ecitonini (Ec), Cryptic Species (CS), Opportunists (Op), Generalized Myrmicinae (GM) and Specialized Predators (SP) (Table 1). In some cases, functional group classification agreed with that of Andersen (2000) when assigning the totality of a genus to a functional group. Some exceptions are small Solenopsis spp. and some Dorymyrmex spp., as well as the two Forelius species. In these cases, we assigned species to different functional groups based on personal observations (Claver) and data from Bestelmeyer and Wiens (1996) and Cuezzo (2000). The group of 
Tropical Climate Specialists (Andersen, 2000) was divided into the Fungus-growing ants (Attini) and the Legionary ants (Ecitonini) because these groups are exclusive to the New World and have no correlations to Australian functional groups on which Andersen based his classification.

\subsection{Data analysis}

We plotted species accumulation curves to determine if sampling effort was adequate to catch all species present in the sites using Coleman's, Jackknife, Bootstrap and Chao 2 models. We then examined the effect of grazing on richness, diversity and total abundance of species and functional group abundance using Generalized Linear Models (GLM) with the software Genstat Discovery Edition 3 (Genstat, 2007). The explanatory variables in all the models were treatment (ranch/reserve) and season. As for the response variables, diversity was estimated using Shannon index. For the richness model, we used estimated richness values based on Coleman's rarefaction curves computed using the software EstimateS version 8.2 (Colwell, 2009). These estimates agreed with those estimated by Bootstrap, Jackknife and Chao 2 models (Fig. 1). For species and functional group abundance,

Table 1 Comparison between functional groups according to Bestelmeyer and Wiens (1996), Andersen (2000), and this study

\begin{tabular}{|c|c|c|c|}
\hline Andersen & Bestelmeyer and Wiens & This study & Functional group characteristics \\
\hline Dominant Dolichoderinae (DD) & $\begin{array}{l}\text { Dominant Dolichoderinae } \\
\text { (DD) }\end{array}$ & $\begin{array}{l}\text { Dominant Dolichoderinae } \\
\text { (DD) }\end{array}$ & $\begin{array}{l}\text { They are highly aggressive and exert dominance } \\
\text { over other ants. Very abundant. }\end{array}$ \\
\hline Subordinate Camponotini (SCa) & $\begin{array}{l}\text { Subordinate Camponotini } \\
\text { (SCa) }\end{array}$ & $\begin{array}{l}\text { Subordinate Camponotini } \\
\text { (SCa) }\end{array}$ & $\begin{array}{l}\text { Subordinate behavior toward dominant species. } \\
\text { Camponotus spp. Large body size and often noctur- } \\
\text { nal foraging. }\end{array}$ \\
\hline Climate Specialists (CS) & Climate Specialists (CS) & Climate Specialists (CS) & $\begin{array}{l}\text { Species that respond to environmental variables such } \\
\text { as temperature and humidity. }\end{array}$ \\
\hline 1. Hot Climate Specialists (HCS) & & $\begin{array}{l}\text { Hot Climate Specialists } \\
\text { (HCS) }\end{array}$ & $\begin{array}{l}\text { Species adapted to arid habitats. They show behav- } \\
\text { ioral, morphological or physiological specializations } \\
\text { that allow them to reduce interactions with dominant } \\
\text { species. We include here some species of Pogono- } \\
\text { myrmex sp. and Forelius sp. }\end{array}$ \\
\hline \multirow[t]{3}{*}{$\begin{array}{l}\text { 2. Tropical Climate Specialists } \\
\text { (TCS) }\end{array}$} & & & $\begin{array}{l}\text { Distribution centered on the humid tropics. Occur in } \\
\text { habitats where dominant species are not abundant. }\end{array}$ \\
\hline & & $\begin{array}{l}\text { a. Attini (At) } \\
\text { (Fungus-growing ants) }\end{array}$ & $\begin{array}{l}\text { Species with tropical or subtropical origin, and from } \\
\text { fungus-growing tribe Attini. Include leaf-cutters as } \\
\text { Acromyrmex sp., and those that use mulch and in- } \\
\text { sects faeces as substrate for fungus as Cyphomyrmex } \\
\text { spp. and Mycetophylax spp. At the Monte Desert } \\
\text { only Acromyrmex spp. occur. }\end{array}$ \\
\hline & & $\begin{array}{l}\text { b. Ecitonini (Ec) } \\
\text { (Legionary ants) }\end{array}$ & $\begin{array}{l}\text { Nomadic legionary species. They prey on other } \\
\text { arthropod species. Species from tribe Ecitonini as } \\
\text { Neivamyrmex sp. }\end{array}$ \\
\hline 3. Cold Climate Specialists (CCS) & & & $\begin{array}{l}\text { Distribution centered on the cool-temperate zone. } \\
\text { Occur in habitats where Dominant Dolichoderines } \\
\text { are generally not abundant. }\end{array}$ \\
\hline Cryptic Species (CS) & Cryptic Species (CS) & Cryptic Species (CS) & $\begin{array}{l}\text { Small-sized species that feed in soil or the ground } \\
\text { layer. They have little interaction with the other } \\
\text { epigeic ants. Include small species of Solenopsis spp. } \\
\text { and Brachymyrmex spp. }\end{array}$ \\
\hline Opportunists (Op) & Opportunists (Op) & Opportunists (Op) & $\begin{array}{l}\text { Not specialized, "ruderal" species, typical from } \\
\text { disturbed areas or habitats with low diversity. In- } \\
\text { cludes Dorymyrmex spp. }\end{array}$ \\
\hline Generalized Myrmicinae (GM) & $\begin{array}{l}\text { Generalized Myrmicinae } \\
(\mathrm{GM})\end{array}$ & $\begin{array}{l}\text { Generalized Myrmicinae } \\
\text { (GM) }\end{array}$ & $\begin{array}{l}\text { Cosmopolitan genera occurring in almost every } \\
\text { habitat. Not very active, or aggressive. Depend on } \\
\text { rapid recruitment and mass mobilization to defend } \\
\text { resources. Include Crematogaster spp., Pheidole } \\
\text { spp., Solenopsis spp. and Zacryptocerus spp. }\end{array}$ \\
\hline Specialized Predators (SP) & Specialized Predators (SP) & Specialized Predators (SP) & $\begin{array}{l}\text { Large- or medium-sized species, and specialized } \\
\text { predators that feed on other arthropods. Low density } \\
\text { and little interaction with other species due to spe- } \\
\text { cialized diet. }\end{array}$ \\
\hline
\end{tabular}



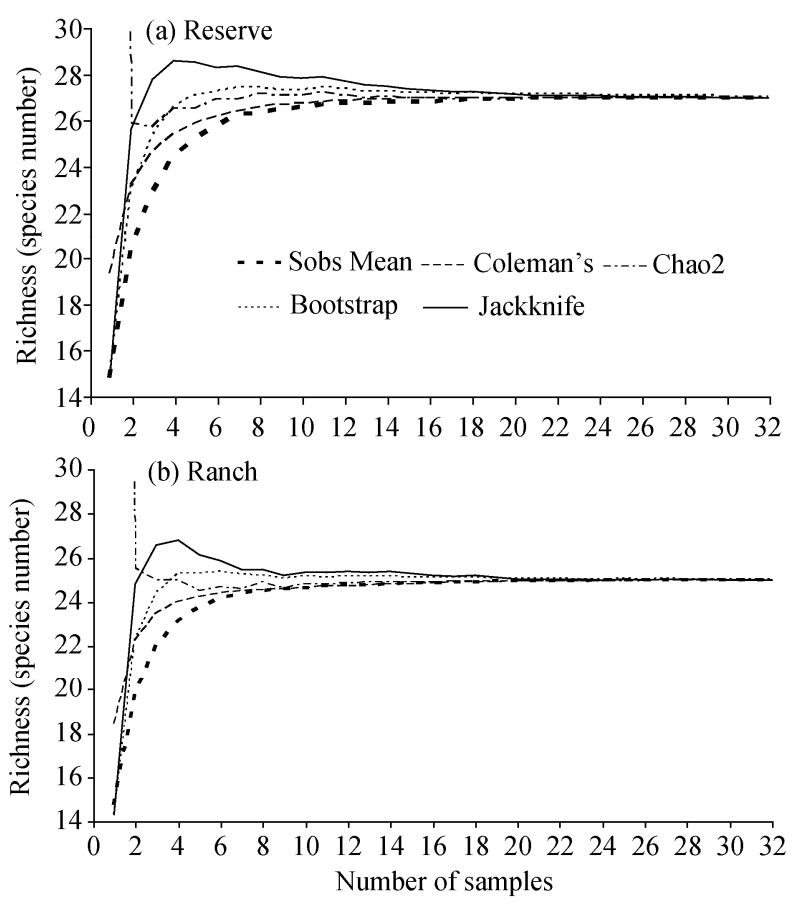

Fig. 1 Species accumulation curves and richness estimation

we used a presence/absence matrix in order to estimate abundance by grid (frequency, see below) (Hoffmann et al., 2000). For data analysis we used seasonal data, but for graphic purposes we pooled all collection events at a site. Each species (or functional group) had a binary response at each trap (presence/absence), resulting in a number of traps occupied by the species over the 12 traps present in the grid. The value of the abundance is the sum of traps in which the species was recorded (present) in each grid. This can vary from 0 to 12 . Relative abundance was calculated by dividing mean abundance with the 12 traps found in the grid. Mean abundance was obtained from the sum of the frequencies of the four replications from each season in each area.

In the GLM, estimated richness and diversity were analyzed assuming a Poisson distribution, whereas species and functional group abundance were assumed to have a binomial distribution (traps present/12 traps). We developed GLM using the statistic $\chi^{2}$ as goodness of fit. When examination of the diagnostics (deviance and df) indicated that the data were overdispersed, they were scaled using the deviance to improve the fit to the model (Crawley, 1993). In this case, the analysis was based on the $F$ probability distribution instead of $\chi^{2}$ distribution (McCullagh and Nelder, 1989; Crawley, 1993; McConway et al., 1999).

\section{Results and discussion}

\subsection{Diversity and functional structure of the ant community}

We identified a total of 27 species of ants. Myrmicinae was the best represented subfamily with 15 species belonging to eight genera, followed by the subfamily Dolichoderinae with eight species within two genera, then Formicinae with three species in two genera and Ecitoninae with one species.

The estimated richness based on Coleman's rarefaction curves was 27 species at the reserve and 25 species at the ranch area (Cephalotes jheringi and Dorymyrmex breviscapis not present). The sampling effort (32 samples) was sufficient to register all the species present in the study area (asymptote of the rarefaction curves of all estimators reached 25 samples at the reserve and 22 samples at the ranch; Fig. 1). Classical descriptors of the community such as richness and diversity were not different between the reserve and the ranch but there were significant seasonal differences with higher richness during the summer $(F=17.64, d f=7, P<0.001)$ and lower diversity during the winter $(F=16.04, d f=7, P<0.001)$ (Table 2$)$. Seasonal changes found are mainly due to the absence of certain species (from the CS, GM, Ec and HCS groups) during the winter, with some of them being absent during the autumn as well. In addition, there is an overall decrease in abundance during the two seasons. This pattern might be related to the lower temperatures as well as food (seeds, flowers, insects, etc.) availability during the cold and dry months of the winter.

Seven of the nine functional groups defined above (Table 1) were present in both the reserve and the ranch, with species of the DD and SP groups not occurring in this study. In the study area, GM and At were the most abundant groups, accounting for $26 \%$ and $25 \%$ of the total abundance, respectively. They were followed by Op (17\%), SCa (12\%), HCS (11\%), CS (7\%) and Ec (2\%) (Fig. 2).

Overall relative abundance of three functional groups changed under disturbance (the ranch). GM 
Table 2 Results from the GLM evaluating the effect of grazing disturbance and season on the response of richness, diversity and relative abundance of ant species and functional groups during the two years of the study

\begin{tabular}{|c|c|c|c|c|c|c|c|}
\hline & \multicolumn{2}{|c|}{ Treatment } & \multicolumn{2}{|c|}{ Season } & \multicolumn{2}{|c|}{ Treatment $\times$ Season } & \multirow[t]{2}{*}{ Response } \\
\hline & $F / \chi^{2}$ & $P$ & $F / \chi^{2}$ & $P$ & $F / \chi^{2}$ & $P$ & \\
\hline Richness & 1.02 & 0.318 & 17.64 & $<0.001$ & 2.94 & 0.012 & \\
\hline Diversity & 0.14 & 0.710 & 16.04 & $<0.001$ & 0.061 & 0.005 & \\
\hline GM & 25.41 & $<0.001$ & 3.08 & 0.009 & 2.47 & 0.030 & Decreaser \\
\hline Crematogaster quadriformis (Myr) & 0.05 & 0.17 & 13.69 & $<0.001$ & 0.79 & 0.597 & \\
\hline Cephalotes jheringi (Myr) & 8.35 & 0.006 & 11.22 & $<0.001$ & 1.08 & 0.394 & Decreaser \\
\hline Pheidole aberrans (Myr) & 6.09 & 0.76 & 10.09 & $<0.001$ & 3.21 & 0.007 & \\
\hline Pheidole bergi (Myr) & 5.26 & 0.022 & 7.500 & $<0.001$ & 3.99 & 0.001 & Decreaser \\
\hline Pheidole sp. 1 (Myr) & 0.51 & 0.479 & 7.71 & $<0.001$ & 0.51 & 0.822 & \\
\hline Pheidole spininodis (Myr) & 13.16 & 0.001 & 28.89 & $<0.001$ & 5.09 & 0.001 & Decreaser \\
\hline Solenopsis saevissima (Myr) & 10.81 & 0.002 & 31.21 & $<0.001$ & 1.81 & 0.107 & Decreaser \\
\hline At & 3.86 & 0.055 & 1.71 & 0.129 & 1.25 & 0.297 & \\
\hline cromyrmex lobicornis (Myr) & 0.12 & 0.724 & 13.56 & $<0.001$ & 1.90 & 0.065 & \\
\hline Acromyrmex striatus (Myr) & 7.67 & 0.008 & 3.11 & 0.009 & 1.24 & 0.302 & Decreaser \\
\hline Cyphomyrmex rimosus (Myr) & 1.49 & 0.228 & 10.71 & $<0.001$ & 0.59 & 0.763 & \\
\hline Mycetophylax bruchi (Myr) & 0.11 & 0.74 & 3.30 & $<0.001$ & 0.34 & 0.940 & \\
\hline Op & 3.86 & 0.055 & 1.71 & 0.129 & 1.25 & 0.297 & \\
\hline Dorymyrmex wolffhuegeli (Dol) & 0.12 & 0.724 & 13.56 & $<0.001$ & 1.90 & 0.065 & \\
\hline Dorymyrmex ensifer (Dol) & 7.67 & 0.008 & 3.11 & 0.009 & 1.24 & 0.302 & Decreaser \\
\hline Dorymyrmex exanguis (Dol) & 1.49 & 0.228 & 10.71 & $<0.001$ & 0.59 & 0.763 & \\
\hline Dorymyrmex sp. 1 (Dol) & 0.11 & 0.74 & 3.30 & $<0.001$ & 0.34 & 0.940 & \\
\hline $\mathrm{SCa}$ & 0.92 & 0.343 & 11.33 & 0.001 & 0.89 & 0.523 & \\
\hline Camponotus mus (For) & 0.92 & 0.343 & 11.33 & $<0.001$ & 0.89 & 0.523 & \\
\hline Camponotus punctulatus (For) & 0.41 & 0.527 & 12.46 & $<0.001$ & 1.42 & 0.221 & \\
\hline $\mathrm{HCS}$ & 4.25 & 0.045 & 9.36 & $<0.001$ & 1.13 & 0.363 & Increaser \\
\hline Forelius chalybaeus (Dol) & 0.38 & 0.542 & 3.05 & 0.010 & 1.92 & 0.080 & \\
\hline Forelius nigriventris (Dol) & 0.73 & 0.396 & 6.79 & $<0.001$ & 1.30 & 0.270 & \\
\hline Pogonomyrmex inermis (Myr) & 8.77 & 0.050 & 5.93 & $<0.001$ & 1.32 & 0.262 & Increaser \\
\hline Pogomomyrmex mendozanus (Myr) & 4.58 & 0.032 & 11.87 & $<0.001$ & 1.06 & 0.388 & Increaser \\
\hline Pogonomyrmex rastratus (Myr) & 0.54 & 0.464 & 13.55 & $<0.001$ & 0.21 & 0.981 & \\
\hline $\mathrm{CS}$ & 5.30 & 0.026 & 42.07 & $<0.001$ & 1.26 & 0.292 & Decreaser \\
\hline Brachymyrmex sp. 1 (For) & 5.30 & 0.026 & 42.07 & $<0.001$ & 1.26 & 0.292 & Decreaser \\
\hline Dorymyrmex carettei (Dol) & 0.21 & 0.654 & 8.46 & $<0.001$ & 1.96 & $<0.05$ & \\
\hline Dorymyrmex breviscapis (Dol) & 4.89 & 0.027 & 51.26 & $<0.001$ & 1.19 & 0.307 & Decreaser \\
\hline Solenopsis sp. 1 (Myr) & 9.77 & 0.002 & 4.29 & $<0.001$ & 0.00 & 1.000 & Decreaser \\
\hline Ec & 1.59 & 0.207 & 7.38 & $<0.001$ & 3.12 & 0.003 & \\
\hline Neivamyrmex sp. 1 (Dor) & 0.01 & 0.925 & 19.59 & $<0.001$ & 1.66 & 0.141 & \\
\hline
\end{tabular}

Note: Subfamily is shown in brackets following the species name. Myr, Myrmicinae; Dol, Dolichoderinae; For, Formicinae; Dor, Dorilinae. Functional group codes are the same as in Table 1.

and CS were more abundant at the reserve whereas the HCS was more abundant at the ranch (Fig. 2; Table 2). There were no differences between treatments in the number of species comprising each group except for the CS and GM groups with one less species at the ranch (Dorymyrmex breviscapis and Cephalotes jherengi, respectively).

Camponotus punctulatus was the most abundant species, followed by Acromyrmex striatus, A. lobicornis, Dorymyrmex ensifer, D. exanguis, Pheidole bergi and Ph. spininodis (Fig. 3). Species abundance between treatments was significantly different for 11 of the 27 species recorded (Table 2). Pogonomyrmex mendozanus and Pogonomyrmex inermis were more abundant at the ranch while the nine remaining species were more abundant at the reserve. 


\subsection{The ant community of the central Monte}

In this part of the central Monte, the richness of the ant community is similar to that of other arid regions such as the northern Monte in Argentina (33 species in Andalgalá, Catamarca; Mares et al., 1977) and the deserts of southern USA with which the Monte shows evolutionary convergence (Mares et al., 1985; Table 3). Compared to other arid regions of Argentina, however, richness at the Monte is intermediate between the Dry Chaco with 63-67 species (Tucumán: Bucher, 1974; Salta: Bestelmeyer and Wiens, 1996), and the Patagonian steppe and scrubland with seven and eight species, respectively (Farji-Brener et al., 2002), following a latitudinal gradient with a decrease in richness towards higher latitudes, from $24^{\circ} \mathrm{S}$ and $63^{\circ} \mathrm{W}$ in Salta to $41^{\circ} \mathrm{S}$ and $71^{\circ} \mathrm{W}$ in Patagonian steppe (Table 3). Similar to richness, the functional structure of the Monte resembles that of the communities from arid areas of southern USA (Andersen, 1997; Nash et al., 2004). The main difference is the absence of DD, as in the Dry Chaco. This can be attributed to biogeographical causes as DD species are not well represented in southern South America. A lower representation of DD in the New World compared to Australia was reported by Andersen (1997). This functional group is of major importance in structuring communities in arid regions of Australia, especially species of the highly specious genus Iridomyrmex, which is absent in the New World.
When comparing the functional structure of ant communities of the central Monte with that of the Dry Chaco, GM stands out as the dominant functional group at the Chaco (more than $40 \%$ ), while at the Monte both GM and At are equally dominant (about $25 \%$ of total abundance each). There are also differences in CS and Ec groups, which are less abundant at the Monte, while HCS is more abundant here (Table 3). The Dry Chaco has higher annual precipitation and a more complex vegetation structure, with a higher proportion of arboreal stratum and litter layer than the Monte (Cabrera and Willink, 1973; Bestelmeyer and Wiens, 1996). CS can find a higher proportion of suitable habitat which enables the coexistence of more

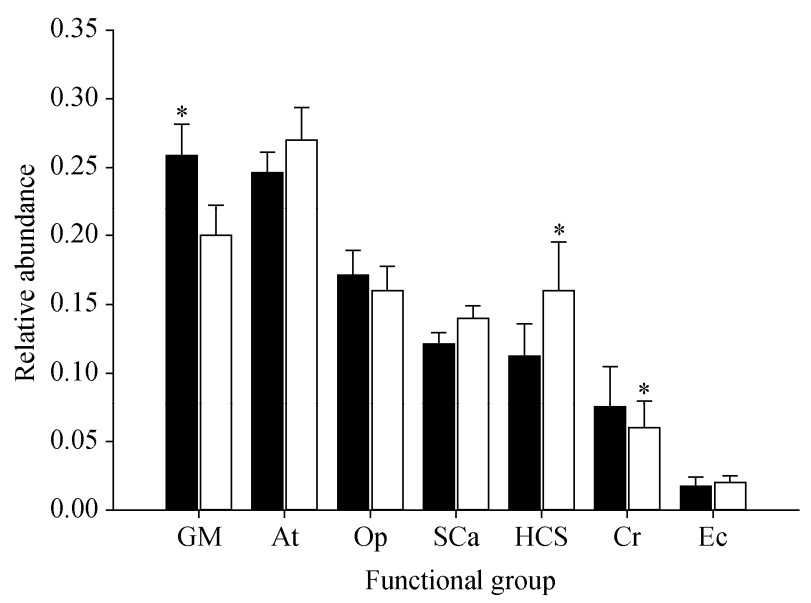

Fig. 2 Relative abundance (and standard deviation) of ant functional groups at the reserve (black bars) and the ranch (white bars). See text for functional group codes. $*, P<0.05$.

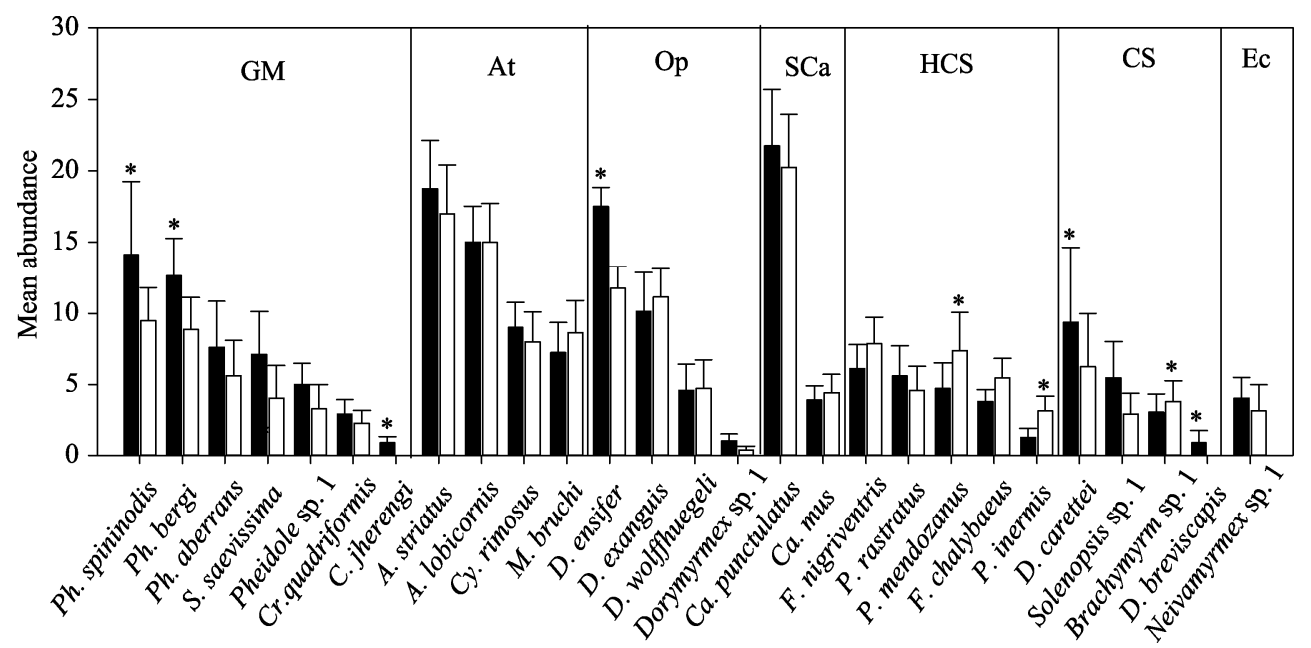

Fig. 3 Mean abundance (and standard deviation) of species found in the central Monte at the reserve (black bars) and the ranch (white bars) grouped by functional groups. Asterisks indicate significant differences in abundance were found between treatments as shown in Table 2. See Table 1 for functional group codes. 
Table 3 Functional group composition (percentage) of ant community in Nacuñan reserve compared with those in arid areas of North America and Australia

\begin{tabular}{|c|c|c|c|c|c|c|c|}
\hline \multirow{3}{*}{ Functional group } & \multirow{2}{*}{$\begin{array}{l}\text { Central Monte } \\
\text { Desert (Nacu- } \\
\text { ñán) }\end{array}$} & \multirow{2}{*}{$\begin{array}{c}\text { Dry Chaco } \\
\text { (Los Colorados, } \\
\text { Salta) }\end{array}$} & \multirow{2}{*}{$\begin{array}{l}\text { Mojave Desert } \\
\text { (Southeastern } \\
\text { California) }\end{array}$} & \multirow{2}{*}{$\begin{array}{l}\text { Sonoran Desert } \\
\text { (Chiricahua } \\
\text { Mountains*) }\end{array}$} & \multicolumn{3}{|c|}{ Australia* } \\
\hline & & & & & WNP & KP & LH \\
\hline & Warm desert & Dry forest & Warm desert & Warm desert & $\begin{array}{c}\text { Heath- } \\
\text { land }\end{array}$ & $\begin{array}{c}\text { Desert } \\
\text { shrub- } \\
\text { land }\end{array}$ & $\begin{array}{l}\text { Open shrub- } \\
\text { land and wood- } \\
\text { land } \\
\end{array}$ \\
\hline Dominant Dolichoderinae & - & - & 32 & 23 & 35 & 33 & 47 \\
\hline Subordinate Camponotini & 12 & 4 & - & 5 & 3 & 11 & 6 \\
\hline Hot Climate Specialists & 11 & 2 & 18 & 17 & 9 & 12 & 22 \\
\hline Cold Climate Specialists & - & - & - & 1 & 2 & - & - \\
\hline $\begin{array}{c}\text { Tropical Climate Specialis } \\
\text { Attini } \\
\text { Ecitonini }\end{array}$ & $\begin{array}{c}25 \\
2\end{array}$ & $\begin{array}{c}14 \\
5\end{array}$ & - & - & - & - & - \\
\hline Cryptic Species & 7 & 21 & - & 1 & 2 & 1 & - \\
\hline Opportunists & 17 & 10 & 25 & 16 & 8 & 13 & 14 \\
\hline Generalized Myrmicinae & 26 & 42 & 25 & 38 & 41 & 28 & 11 \\
\hline Specialist Predators & - & 2 & - & - & - & 1 & - \\
\hline Total number of species & 27 & 67 & 33 & $18-28$ & - & - & $16-42$ \\
\hline
\end{tabular}

Note: -, not recorded in the study. Data from the Dry Chaco were provided by Brandon BESTELMEYER and were taken at the highly restored site of Bestelmeyer and Wiens (1996). Data from the Mojave Desert site (Nash et al., 2004) are the average of six sites, each site with traps located at different distances from a water tank; ant species were assigned to functional groups based on Andersen's classification of North American ant fauna (Andersen, 1997). Sonoran Desert data are an average of catches at three sites located between 1,400-1,500 m asl at the Southwestern Research Station in the Chiricahua Mountains of southeastern Arizona, USA. Australian sites are as follows: WNP, Wyperfeld National Park in the semi-arid southeastern Australia (mean of adjacent heath and mallee sites; Andersen, 1983); KP, Kunoth Paddock in central Australia (Greenslade, 1978); LH, Lawn Hill station in the semi-arid tropics of Queensland (Andersen, 1993). *, data taken from Andersen (1997).

species and larger populations of CS at the Chaco. Conversely, the higher abundance of HCS at the Monte is probably due to the high proportion of highly insolated open areas. In fact, Bestelmeyer and Wiens (1996) found that the ant fauna in their highly disturbed habitat ("puesto") is similar to that of the Monte (though with higher richness: 63 species). This suggests that conditions of simplified vegetation structure with less herbaceous stratum are suitable for species of more arid areas. In addition, the higher richness of the "puesto" can be explained by the effect of regional diversity at the local scale. At a regional scale, the Chaco region has more ant species than the Monte Desert, and this can affect the available pool of species at local scales (Harrison and Cornell, 2008). Within these lines we find a lower number of species and abundance of Ec in the Monte (with only one species accounting for $2 \%$ of abundance) compared to the undisturbed Chaco. Ec is a group with origins in northern South America (Lattke, 2003), with the Monte within the southern limits of its range.

\subsection{Differences between the reserve and the ranch}

Richness and diversity indices did not have an effect of grazing disturbance on ants although certain species responded to changes in abundance and affected the community structure. HCS responded to disturbance as increasers, while GM and CS responded with a decrease in abundance. Bestelmeyer and Wiens (1996) reported that in the Dry Chaco the structural simplification of habitat favours the Op and HCS groups. Although we did not find a response of Op, HCS was positively affected. All species comprising each of these functional groups followed the same trend as the overall group, the only two exceptions being Pogonomyrmex rastratus in the HCS group and Brachymyrmex sp. 1 in the CS group (Fig. 3). Finally, the At and SCa groups showed no change under grazing disturbance, similar to what Bestelmeyer and Wiens (1996) found at the Dry Chaco.

In their review on responses of ants to disturbance in Australia, Hoffmann and Andersen (2003) found six studies dealing with livestock grazing. They found a 
consistent response of HCS (increasers) and CS (decreasers) to grazing, agreeing with the results from our study. GM, however, showed inconsistent responses, behaving as increasers in two studies (Read and Andersen, 2000; Hoffman, 2001) and as decreasers in another study (Scougall et al. 1993). Evidence showing that GM is negatively affected by increases in insolation comes from the review by Crist (2009) who mentioned that increases in insolation as a result of habitat disturbance favour DD species, whereas negatively affect $O p$ and GM.

\subsubsection{Hot Climate Specialists}

The higher abundance of HCS at the ranch area can be explained by the increase in insolation due to a decrease in ground cover caused by grazing. This, in turn, increases the amount of suitable microhabitat for HCS. This response of the HCS group has been found in several studies (Bestelmeyer and Wiens, 1996; Hoffmann et al., 2000; Read and Andersen, 2000).

Four of the five species comprising the HCS group showed a tendency to increase at the ranch area but only the increase of Pogonomyrmex mendozanus (Cuezzo and Claver, 2009) and P. inermis was statistically significant (Table 2). Pogonomyrmex species are granivores adapted to arid areas (Kusnezov, 1951, 1963). The diet of Pogonomyrmex species recorded in this study is comprised by a $90 \%$ of grass seeds (Pirk and Lopez de Casenave, 2006; Claver and Marone, unpublished data). P. mendozanus nests on patches of bare ground with high insolation at the mesquite forest (Pirk and Lopez de Casenave, 2006; Claver, unpublished data). $P$. inermis nests in open areas but with herb cover (e.g. deforested areas secondarily colonized by grasses or creosotebush habitats) (Claver, unpublished data). Thus, the habitat conditions with a higher proportion of bare ground and less grass cover at the ranch (Kufner and Chambouleyron, 1991; Gonnet, 1998) could explain the increase in the Pogonomyrmex species despite their dependence on grass seeds for food. At the ranch, these species could expand their diet as $P$. mendozanus does at the reserve during the spring when they include in their diet seeds and flowers of the saltbush Atriplex lampa (Chenopodiacea) (Pirk and Lopez de Casenave, 2006; Claver and Marone, unpublished data). In addition to expanding their diet at the ranch, Pogonomyrmex species could also use grasses in areas of the ranch that are away from the reach of cattle such as under spiny shrubs.

Other species in the HCS group are Forelius nigriventris and $F$. chalybaeus which are collector-predators (Bruch, 1916; Bucher, 1974; Cuezzo, 2000). These species nest on bare ground and are active during the day at hours of high temperatures (which can reach above $50^{\circ} \mathrm{C}$ ) (Claver, personal observations). $F$. nigriventris is a stress-tolerant, thermophilic species (Bucher 1974; Bestelmeyer 1997; Claver, personal observations). At the Dry Chaco, Bestelmeyer (1997) reported that $F$. nigriventris was more active at degraded sites than at sites with forest in recovery. Thus, it is possible that habitat requirements of the HCS group explain their increase in abundance at the ranch.

\subsubsection{Generalized Myrmicinae}

GM was more abundant at the reserve. Together with Attini, this is the most important group in terms of relative abundance in the community. Of the seven species within this functional group, four of them showed a significant response to disturbance, with all seven species showing the same trend. This is a heterogeneous group with respect to diet: Solenopsis saevissima and Pheidole bergi are omnivores whereas $P h$. spininodis and $P h$. aberrans are granivores. Granivores would be favoured at the reserve by the higher abundance of grasses. In addition, these are species that avoid those hours of maximum insolation (Solenopsis is more active at night and nests in areas with abundant litter layer; Claver, personal observations). In any case, they would find better food and habitat conditions at the reserve than at the ranch.

\subsubsection{Cryptic Species}

Similar to the GM, CS such as Dorymyrmex carettei, D. breviscapis and Solenopsis sp. 1 decreased in abundance at the ranch. These are small species commonly found in the litter layer. They would find more suitable microhabitats at sites with higher diversity of microhabitats and higher proportion of soil covered by litter, such as the reserve. Hoffmann and Andersen 
(2003) mentioned that the CS constitutes a good indicator group as they consistently behave as decreasers when found in disturbed areas regardless of the disturbance source.

\subsubsection{Opportunists}

Although the Op group did not show a significant response to grazing in this study, their response was close to the significant level $(P=0.055)$. This was mainly due to the influence of Dorymyrmex ensifer, the most abundant species of the group, which was statistically more abundant in the reserve. Bestelmeyer (1997) considered this species as cold-tolerant given that at the Chaco D. ensifer is active at night with temperatures reaching $5-7^{\circ} \mathrm{C}$. Its temperature tolerance range is broad and can extend to $44^{\circ} \mathrm{C}$ (while soil temperature can reach $60^{\circ} \mathrm{C}$ ). D. ensifer's tolerance to low temperatures may explain their higher abundance at the reserve where they can find shelter from high temperatures and be active when most species are inactive due to low temperatures. In well forested areas of Australia, low disturbance such as fire and grazing favours DD and HCS due to habitat simplification and higher insolation with a decrease of Op (Hoffman and Andersen, 2003). In our study, DD was absent but HCS and Op have the same response as in Australia. The difference is that GM and Op do not show opposite responses as reported by Hoffmann and Andersen (2003). Thus, it is possible that although the Op might be released from the competitive interaction with GM species, environmental conditions of higher insolation at the ranch prevent them from increasing at this site.

\subsection{Adequacy of the functional group approach}

Most studies using the functional group approach have been carried out in Australia and the USA (Hoffman, 2010). In the arid areas of the southern USA, the utility of ants as indicators of livestock grazing impact is equivocal (Nash et al., 2004). In Australia, however, ants have been proven to be good indicators of disturbance (Majer, 1983; Andersen et al., 2002). Nevertheless, Hoffmann and Andersen (2003) argued that functional groups are particularly useful when disturbance causes substantial changes in habitat structure, especially in the litter layer (e.g. Leal et al., 2012), but of least use in open habitats such as arid areas.
Although we did not find a response in all functional groups for this study, some groups did respond. In fact, the functional structure of the community changed, having At as the dominant group, followed by GM, HCS and Op with equal importance. In addition, they responded when grazing causes changes in the vegetation structure and increases insolation. Thus, although it is necessary to carry out more studies to examine whether the response of ants to grazing disturbance is consistent, the results from this study support the use of functional groups as disturbance indicators in arid regions.

Soils at the Monte Desert are poor in nutrients (Tankilevich, 1971) and it is possible that the nitrogen input from cattle urine and faeces is significant. However, with the data currently available, it is difficult to determine whether this factor affects the ant community and its functional structure. If this were the case, we would expect an indirect effect on ants through vegetation (differences in seed abundance, nutrient contents of plants, etc.). Functional groups in this study follow those of Andersen (1987, 1995) which were defined based mainly on habitat requirements (and less on trophic structure). Thus, we argue that change in functional groups in this study was a response to differences in microhabitat conditions such as insolation mediated through variations in vegetation structure and not to possible differences in nitrogen input through cattle.

\section{Conclusions}

In this study, we described the functional structure of the ant community of the central Monte at the Nacuñán Biosphere Reserve and examined its response to grazing disturbance using traditional descriptors and the functional group scheme. Although there were differences in community structure and the differences in abundance of certain functional groups were recorded, they were not reflected in the traditional descriptors such as richness and diversity. HCS increased at disturbed conditions while CS and GM decreased. This constitutes supportive evidence for the use of functional groups in community studies.

When assessing different taxa as disturbance indicators, ants performed better than other invertebrate 
groups such as spiders and hemipterans (Crist, 2009). However, because the response of ant functional groups to disturbance will differ depending on the nature of the disturbance as well as on the habitat where the disturbance occurs, it is important to carry out studies at different regions and habitat types. In tropical forests, for example, there is a decrease in specialized functional groups such as CS and SP as a response to forest fragmentation (Atlantic forest in Brazil; Leal et al., 2012). However, in arid areas such as the Monte Desert these specialized groups are poorly represented (SP did not occur in our study and only one species in the CS was present) and the response to disturbance is due to changes in groups favored under arid conditions, such as HCS.

There are several studies on ant communities in South America, with, however, only few examining functional groups of ants. Our study constitutes the first of its kind conducted in the Monte Desert. Although it is necessary to carry out more studies to examine whether the response of ants to grazing disturbance is consistent, the results from this study support the use of functional groups as disturbance indicators in arid regions.

\section{Acknowledgements}

This work was partially funded by a grant from the National Council of Research (Argentina) Number 4678 for the project "Insect Biodiversity of the Monte". We would like to thank Ana M SCOLLO for helping in trap processing and preparation of the ant collection and to Pablo ECHEVERRIA for assistance at the field work. Dr. Brandon BESTELMEYER generously shared data to include in Table 2.

\section{References}

Abraham E, Boshoven J, Claver S. 2001. Reserve zoning. In: Claver S, Roig-Juñent S. The Monte Desert: Ñacuñán Biosphere Reserve. Córdoba, Argentina: UNESCO-ORCYT-MAB, 107-112.

Agosti D, Majer J, Alonso L, et al. 2000. Ants: Standard Methods for Measuring and Monitoring Biodiversity. Washington \& London: Smithsonian Institution Press.

Andersen A N. 1987. Ant community organization an environmental assessment. In: Majer J D. The Role of Invertebrates in Conservation and Biological Survey. Western Australia Department of Conservation and Land Management Report, 43-52.

Andersen A N. 1991. Parallels between ants and plants: implications for community ecology. In: Huxley C R, Cutler D F. Ant-Plant Interactions. Oxford: Oxford University Press, 539-558.

Andersen A N. 1995. A classification of Australian ant communities based on functional groups which parallel plant life-forms in relation to stress and disturbance. Journal of Biogeography, 22: 15-29.

Andersen A N. 1997. Functional groups and patterns of organization in North American ant communities: a comparison with Australia. Journal of Biogeography, 24: 433-460.

Andersen A N. 2000. A global ecology of rainforest ants: functional groups in relation to environmental stress and disturbance. In: Agosti D, Majer J D, Alonso L E, et al. Ants: Standard Methods for Measuring and Monitoring Biodiversity. Washington, D.C.: Smithsonian Institution Press, 25-34.

Andersen A N, Hoffmann B D, Muller W J, et al. 2002. Using ants as bioindicators in land management: simplifying assessment of ant community responses. Journal of Applied Ecology, 39: 8-17.

Bestelmeyer B, Wiens J. 1996. The effects of land use on the structure of ground-foraging ant communities in the Argentine Chaco. Ecological Applications, 6: 1225-1240.

Bruch C. 1916. Contribution to the study of San Luis Province ants. Revista del Museo de La Plata, 23: 291-357.

Bucher E H. 1974. Ecological observations about chacoan forest arthropods of Tucuman. Revista de Facultad de Ciências Exatas, Físicas y Naturales de Córdoba (Nueva Série) Biología, 1: $35-122$.

Cabrera A, Willink A. 1973. Latinamerican Biogeography ( $\left.2^{\text {nd }} e d.\right)$. Washington, D.C.: OEA, 122.

Claver S, Fowler H. 1993. The ant fauna (Hymenoptera, Formicidae) of the Ñacuñán Biosphere Reserve. Naturalia (São Paulo), 18: 189-193.

Claver S. 2000. Ecology of Acromyrmex lobicornis in Ñacuñán Biosphere Reserve, Monte biogeographic province. Habitat preference, colony abundance, resource use and activity patterns. Ph.D. Thesis. La Plata: Universidad Nacional de La Plata, 160.

Cuezzo F. 2000. Revision of the genus Forelius (Hymenoptera: Formicidae: Dolichoderinae). Sociobiology, 35: 197-277.

Estrella H, Boshoven J, Tognelli M. 2001. Regional and Ñacuñán Reserve climate characteristics. In: Claver S, Roig-Juñent S. Monte Desert: Ñacuñán Biosphere Reserve.

Farji-Brener A G, Corley J C, Bettinelli J. 2002. The effects of fire on ant communities in north-western Patagonia: the importance of habitat structure and regional context. Diversity and Distribution, 8: 235-243.

Hoffmann B D, Griffiths A D, Andersen A N. 2000. Responses of ant communities to dry sulfur deposition from mining emissions in semi-arid Tropical Australia, with implications for the use of functional groups. Austral Ecology, 25: 653-663.

Hoffmann B D. 2001. Responses of ant communities to land use impacts in Australia. Ph.D. Thesis. Darwin: Northern Territory University.

Hoffmann B D, Andersen A N. 2003. Responses of ants to disturbance in Australia, with particular references to functional groups. Austral 
Ecology, 28: 444-464.

Hoffmann B D. 2010. Using ants for rangeland monitoring: global patterns in the responses of ant communities to grazing. Ecological Indicators, 10: 105-111.

Lattke J E. 2003. Biogeography of Neotropical ants. In: Fernández F. Introduction to Ants of the Neotropical Region. Biological Resources Research Institute Alexander von Humboldt.

Majer J D. 1983. Ants: bioindicators of mine site rehabilitation, land-use, and land conservation. Enviromental Management, 7: 375-383.

Mares M A, Blair W F, Enders F A, et al. 1977. The strategies and community patterns of desert animals. In: Orians G H, Solbrig O T. Convergent Evolution in Warm Deserts. An Examination of Strategies and Patterns in Deserts of Argentina and the United States. Stroudsburg-Pennsylvania: Dowden, Hutchinson \& Ross, 107-164.

Mares M A, Morello J, Goldstein G. 1985. The Monte desert and other subtropical semi-arid biomes of Argentina, with comments on their relation to North American arid areas. In: Evenari M, Noy Meir I, Goodall G. Hot Deserts and Arid Shrublands, Ecosystems of the World. Amsterdam-Oxford-New York: Elsevier, 203-237.

Nash M S, Bradford D F, Franson S E, et al. 2004. Livestock grazing effects on ant communities in the eastern Mojave Desert, USA. Ecological Indicators, 4: 199-213.

Pirk G I, Lopez de Casenave J. 2006. Diet and seed removal rates by the harvester ants Pogonomyrmex rastratus and Pogonomyrmex prono- talis in the central Monte desert, Argentina. Insectes Sociaux, 53: $119-125$.

Read J L, Andersen A N. 2000. The value of ants as early warning bioindicators: responses to pulsed cattle grazing at an Australian arid zone locality. Journal of Arid Environment, 45: 231-251.

Roig F, Rossi B E. 2001. Flora and Vegetation. In: Claver S, Roig-Juñent S. The Monte Desert: Ñacuñán Biosphere Reserve. Córdoba, Argentina: UNESCO-ORCYT-MAB, 41-70.

Schnell M, Pik A J, Dangerfield J M. 2003. Ant community succession within eucalypt plantations on used pasture and implications for taxonomic sufficiency in biomonitoring. Austral Ecology, 28: 553-565.

Schofield C J, Bucher E H. 1986. Industrial contributions to desertification in South America. Trends in Ecology \& Evolution, 1: 78-80.

Scougall S A, Majer J D, Hobbs R J. 1993. Edge effect in grazed and ungrazed Western Australian wheatbelt remnants in relation to ecosystem reconstruction. In: Saunders D A, Hobbs R J, Erlich P R. Nature Conservation 3: Reconstruction of Fragmented Ecosystems. Chipping Norton, NSW: Surrey Beatty \& Sons, 163-78.

Tadey M, Farji-Brener A G. 2007. Indirect effects of exotic grazers: livestock decreases the nutrient content of refuse dumps of leaf-cutting ants through vegetation impoverishment. Journal of Applied Ecology, 44: 1209-1218. 